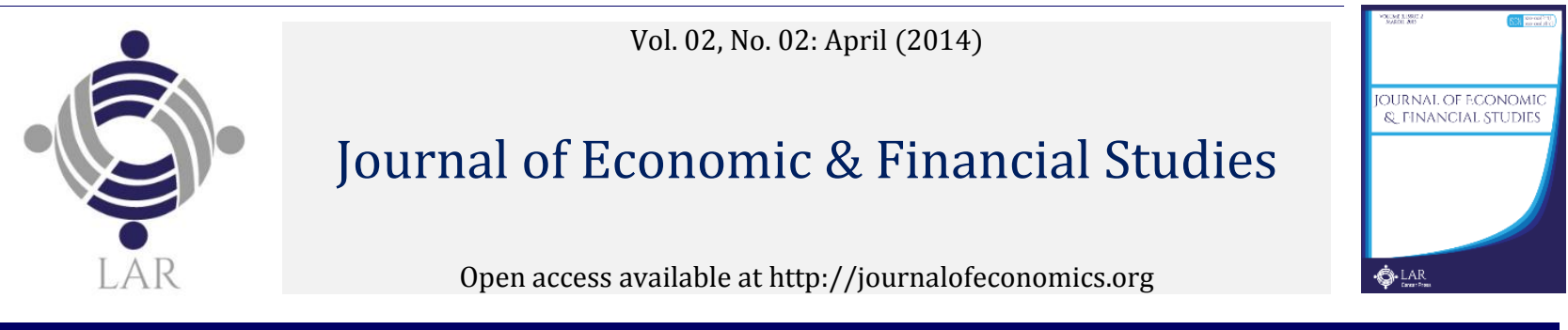

\title{
Delayed effects of graduate education on increased productivity
}

\author{
John Simister $\mathrm{a}^{*}$ \\ a Senior Lecturer, Department of Accounting, Finance \& Economics, Manchester Metropolitan University. \\ * Corresponding author's address: New Business School building, All Saints, M15 6BH, UK. E-mail: \\ j.g.simister@mmu.ac.uk
}

\begin{abstract}
H I G H L I G H T S :
1. There is a strong link between university education and productivity, in international data.

2. If the number of students rises, there will be a delay of several years before the resulting productivity rise.

3. Part of the delay between leaving education and productivity rise is because graduates take time to find jobs.

4. The first job after university is often low-paid; graduates usually take a few years to achieve promotion, and they may be promoted in two or more steps.
\end{abstract}

\author{
Article History \\ Received: 16-02-2014 \\ Accepted: 20-03-2014 \\ Keywords: \\ Granger causality; \\ Graduates; \\ Productivity; \\ Tertiary education.
}

Available online: 24-03-2014

JEL Classification:

H52; I210; J24.

(C) 2014 The Authors. This is an open access article under the terms of the Creative Commons Attribution License 4.0, which allows use, distribution and reproduction in any medium, provided the original work is properly cited.

\begin{abstract}
A B S T R A C T
'Human Capital Theory' shows that education is a vital part of improving productivity. This paper investigates effects of tertiary education (post-school education: at universities, higher-education colleges, and similar institutions) on how productive an employee is. A problem with such research is to identify which variable is the cause, and which is the effect. This paper uses time-series regression analysis of World Bank data, on the fraction of a country's workforce with tertiary education, and productivity. This paper also uses Britain as a case study: the British Household Panel Study shows what happens to a graduate in the years after they leave university. The delayed effects of education on output makes clear that education is a cause (rather than an effect) of improvements in productivity. In conclusion, university-level education is beneficial to economic growth.
\end{abstract}

DOI: http://dx.doi.org/10.18533/jefs.v2i02.53

\subsection{Introduction}

This paper investigates the hypothesis that 'tertiary education' (post-school education, which usually takes place in a university or college) improves productivity. Education qualifications vary between countries, making comparison difficult; this paper uses the World Bank (2013) definition of 'tertiary education', which is similar to 'higher education'. This paper uses the term 'graduate' for a person leaving college or university with any higher education (i.e. post-school) qualification.

There are many ways education could help economic performance: for example, accountancy knowledge might make a person a better manager. Data sources used for this paper do not report academic subjects studied, so it is beyond the scope of this paper to assess if science education is more or less important than social science to raise productivity. 
Gordon (2009) suggested an imminent transition from the 'computer age' to the 'cyber-mental age': automation will give way to innovation and intelligent machines, and 'skilled labor' replaced by 'knowledge labor'. Holland et al. (2013: 23) wrote "In recent years the contribution of tertiary education to countries' economic success has become the focus of greater attention, since tertiary education is expected to support the supply of skilled workers and enhance the conditions for innovation, bringing substantial social and economic benefits" ... "amongst the empirical evidence analyzing the effect of education on growth across countries, only a few papers explicitly analyze the role of tertiary education."

Education may have positive 'externalities': if one person is more educated, other people also benefit (for example, a scientist is more likely to discover new medicines if he or she is better-educated). Emerging technologies such as nanotechnology, service robots (industrial and domestic), and space travel may help humanity, but "Fewer younger workers are enrolling in educational programs that prepare them for these emerging careers and job opportunities" (Gordon, 2009: 10). Economists often describe education as a 'merit good', i.e. a good which is desirable for society as a whole; increasing productivity could raise national income, hence benefitting society in general.

\section{$2.0 \quad$ Literature review}

Conventional economic analysis includes 'human capital theory', which claims education confers skills. Education could work at three levels:

(1) Skills increase productivity of the person educated. For example, graduates with computer skills tend to be more productive (Bapna et al., 2013).

(2) A firm with a large fraction of graduates tends to be more effective (Gordon, 2009): for example, a manager with a degree may help his or her colleagues to produce more efficiently.

(3) Education confers indirect benefits, because technological progress is associated with educated workers (Holland et al., 2013: 12). Hence, firms may benefit from locating in a country with an educated workforce. This is central to 'endogenous growth models'.

'Signalling theory' (an alternative to human capital theory) claims labour market performance depends on factors such as personality, rather than education (Quiggin, 1999). It suggests education divides people into 'winners and losers': there are undesirable jobs such as cleaners, and desirable jobs such as presidents. Society could decide who will be rich by, for example, testing everyone at five years of age.

Does higher education improve productivity (as human capital theory claims), or does it have no effect on productivity (as signalling theory implies)? Department of Employment and Learning (2009: 32) found "a strong association exists across UK regions and local areas between the percentage of graduates working in the private sector and the average wages of all employees. A similar relationship exists between graduates and productivity" ... "A large amount of data has been collected, and analyses conducted, to ensure that the variables are measured correctly and consistently, and as far as possible that the relationships remain unchanged over time" ... "Our conclusion is also that the relationship is largely causal, in the sense that concentrations of graduates in a local economy lead to higher productivity and higher wages for all employees and not just for the graduates themselves." Fox \& Smeets (2011), analysing Danish data on 8 industries, report that the fraction of a firm's labour force with a degree explains some productivity difference between firms. Almost all of the empirical studies analysed by Holland et al. (2013: 17) found positive and significant effects of human capital on growth. Holland et al. (2013: 8) analysed European data from 1994 to 2005, concluding that at least a third of the productivity rise can be attributed to the increasing number of graduates. Hanushek and Wößmann (2007: 7) report that by adding educational quality to a regression with economic growth as the dependent variable, the variation explained rose from $25 \%$ to $73 \%$. Organisation for Economic Co-operation and Development (2012: 68) claim education increases GDP growth-rates. Other evidence supports human capital theory \& rejects signalling theory (Rohling, 1986; Simister, 2011).

Evidence reported in the previous paragraph indicates education raises productivity; but there is disagreement about how. Perhaps graduates are better managers (Holland et al., 2013: 60). Fox \& Smeets (2011: 966) suggest firms hire graduates to supervise (less well-paid) non-graduate employees; graduate and non-graduate labour are complementary (other economists see graduates as substitutes, rather than complements, for non-graduate employees). University-educated employees are better able to use computer software (Holland et al., 2013: 24); universities also provide specialist skills (Pissarides, 2011: 228), such as solar panels; electric cars; and 3D printers. "An emerging Cyber-Mental Age will give the well-educated person the power to innovate products and services by using very advanced technologies" (Gordon, 2009: 3).

Another way education could raise productivity is via Research \& Development (R\&D). Cockburn \& Slaughter (2010: 145) claim "relative costs of R\&D activity are ultimately determined in part by national relative supplies of these skilled workers - again, a point that resonates with discussion of international differences in tertiary graduation rates". Rich countries such as USA face increased competition: "The large number of science and 
engineering graduates in China and India combined with the lower wages in those countries makes them attractive sites for multinational R\&D facilities" (Freeman \& Van Reenen, 2009: 5). Cockburn \& Slaughter (2010: 135-6) report a declining share of patents in USA, associated with increasing patent applications in Asia. Similar trends apply to clinical trials: United States, Europe, and Japan "together account for $80 \%$ of global clinical research. Note, however, that the share of the emerging regions has grown substantially. Over the 5 years 2003-8, the traditional regions' share in activity fell at about $2 \%$ per year, whereas the emerging regions' share in activity grew at about $10 \%$ per year. Much of the expansion in activity outside the traditional locations has occurred in Eastern European countries and Asia" (Cockburn \& Slaughter, 2010: 137).

Falling R\&D spending in USA and Europe (relative to other countries such as China) could be because of university funding. Universities are important for private-sector investment: "Asked to rate the importance of a variety of factors influencing location choice, $R \& D$ managers in this sample rated IP protection, access to qualified research personnel, and opportunities to collaborate with local universities much more highly than cost advantages or absence of regulatory restrictions" (Cockburn \& Slaughter, 2010: 141). Government investments in research can increase a country's international economic competitiveness (Freeman \& Van Reenen, 2009: 7). Pharmaceutical firms gain from locating in countries where academic research occurs (Cockburn \& Slaughter, 2010: 138), and "proximity to publicly funded science appears to be an important determinant of research productivity" ... "patenting by pharmaceutical companies is positively correlated with the volume of academic publications by "local" public-sector scientists" (Cockburn \& Slaughter, 2010: 139). "About 60\% of basic research in the United States is conducted in universities, largely funded by the federal government" (Freeman \& Van Reenen, 2009: 5). Lefrere (2007: 204) suggests that while élite European universities have sufficient funding for equipment, middle and lower ranking European universities find it increasingly difficult to compete with universities in China and elsewhere. Business leaders in USA (especially in high-tech sectors), worried about increased foreign competition and declining comparative advantage in R\&D-intensive industries, argue for increased government education subsidies (Freeman \& Van Reenen, 2009: 2). Freeman \& Van Reenen (2009: 4) wrote "The U.S. share of science and engineering activity around the world is declining" ... "This decline is inevitable as the rest of the world catches up to the United States in higher education and R\&D".

Private firms tend to underinvest in education \& training (Freeman \& Van Reenen, 2009: 7), perhaps because employees could accept training at one firm, and then work for a rival firm (Wang et al., 2009: 1267). Cockburn \& Slaughter (2010: 154) refer to a "global war for talent". Gordon (2009: 8) wrote "A rising tide of applicants does not meet the minimum qualifications for an increasingly sophisticated world of work". European Commission (2010: 9) wrote "Serious deficits in qualified professionals, in management and technical, job-specific skills are hampering Europe's sustainable growth objectives. This is also the case for shortages in areas critical for innovation". Gordon (2009: 1-2) reports research from 32 countries, which indicates many employers have difficulty filling jobs.

Education spending is thought to have two separate but inter-related effects on productivity: increasing the international competitiveness of the country where spending takes place, and increasing global productivity helping all countries (Cockburn \& Slaughter, 2010: 155; Freeman \& Van Reenen, 2009: 8).

This paper does not report evidence on whether university-based research is more, or less, valuable than the training of graduates. Perhaps the interaction between university research and teaching (e.g. where students are taught by researchers at the frontier of research) is ideal. The remainder of this paper tests the hypothesis (based on 'human capital theory') that tertiary education tends to increase productivity.

\subsection{The materials and methods}

This paper investigates effects of education on productivity. Three types of data are used: global macroeconomic data, with annual data for a country as a whole; and for Britain, data on individual persons from two British household surveys. The EUKLEMS database is a possible data source: Holland et al. (2013: 53) use average growthrate (over several years) for each country they study; but EUKLEMS covers only advanced economies (Holland et al., 2013: 18), and "the relationship between education and growth is sensitive to the stage of development".

World Bank use data from national governments, intended to provide data comparable between countries. For this paper, the first data source is 'World Development Indicators' (WDI), from World Bank (2013). Productivity is assessed using World Bank data on 'value added' (series NV.IND.TOTL.KD), reported in US\$; the author converted productivity to constant 2012 prices using USA prices (WDI series FP.CPI.TOTL). This was divided by labour force (series SL.TLF.TOTL.IN), for Chart 1; the same data are used for regression (see appendix). This dependent variable estimates the value of each employee's work (the average of all workers in the country, including graduates and non-graduates). The 'value added' data are more appropriate than the value of output: for example, in a factory 
assembling cars, the value of components bought by the firm (engines, batteries, headlights, etc.) should be subtracted from the value of cars sold, when assessing the productivity of the factory's workers.

For Chart 2, WDI variable IP.PAT.RESD (the number of patents applied for by that country's residents) is divided by that country's labour force. Chart 3 uses number of trade mark applications by a country's residents (series IP.TMK.RESD), again divided by size of the country's labour force.

In macroeconomic data such as the World Bank data described above, it is impossible to control for variables such as an employee's work experience. To investigate an individual employee's productivity, microeconomic data are used as the second and third data sources for this paper. The second data source is household surveys, carried out by the UK government: 'Family Expenditure Survey' data from 1979 to 2000/1, combined with 'Expenditure and Food Survey' data for 2001/2 to 2006/7, and 'Living Costs and Food Survey' from 2008 to 2011. These three groups of surveys are referred to in this paper as FES. Each FES survey is a large nationally-representative survey of the UK, providing data on about 13,000 people (UK Data Service, 2013); unweighted data are used. FES reports income from different sources; this paper uses income from bonuses (a component of pay which is performancerelated): variable b312p in most FES surveys. FES also report the age each adult left full-time employment (people aged below 18, and adults still in education, are excluded from analysis in this paper). The number of years since leaving full-time education is calculated by subtraction, and (to simplify table 2) people who left education 12 or more years ago are grouped into one category.

This paper also uses data from a third source, the 'British Household Panel Study' (BHPS) waves 1 to 19, from 1991 to 2009 (University of Essex, 2010). This is a representative sample of British households, in which respondents are interviewed (if possible) every year. The author calculated the number of years since each person left full-time education, and limited the sample to people with a degree, HND, HNC, or teaching qualification, from variable QFACHI (Taylor et al., 2010: App2-19). If a person returned to education, the first time they left university/college is used.

\subsection{Results and discussions}

Training by commercial firms is a substitute for university education; but World Bank (2013) data indicate only $38 \%$ of firms offer any training to their employees (a weighted average of all available years \& countries: series IC.FRM.TRNG.ZS).

Chart 1 uses data from all countries in World Bank (2013): the height of each line is average productivity, weighted by the country's population (SP.POP.TOTL). Empirical research often distinguishes between workers with or without a college/university degree (Fox \& Smeets, 2011: 966); definitions of 'tertiary education' are discussed in United Nations Educational, Scientific and Cultural Organisation (2012). The control variable in Chart 1 (SL.TLF.TERT.ZS) is "the proportion of labor force that has a tertiary education" (World Bank, 2013); the author divided this into three categories. For this paper, the key lesson is that countries with more educated workforces tend to be more productive, than countries with less educated employees: the line for countries with over $20 \%$ in their workforce is much higher than the other two lines in Chart 1.

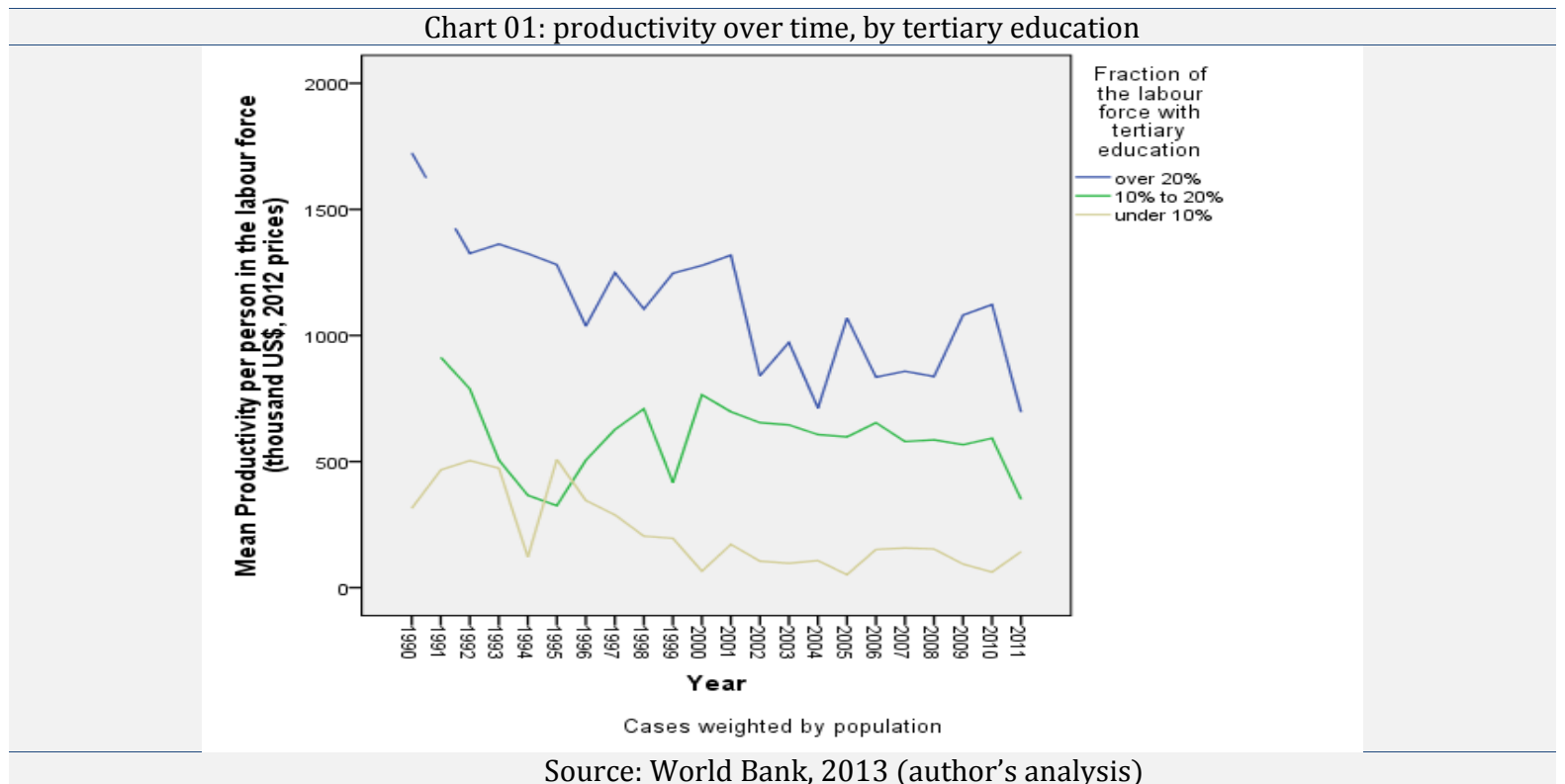

Source: World Bank, 2013 (author's analysis) 
There are reasons for caution regarding Chart 1 . Productivity is influenced by many factors, such as capital investment; unemployment; and civil war. Chart 1 could give an accurate picture (despite such complications) if World Bank data is a representative sample including - for example - rich and poor countries. But the sample may be biased (e.g. data are more likely to be missing for a country at war).

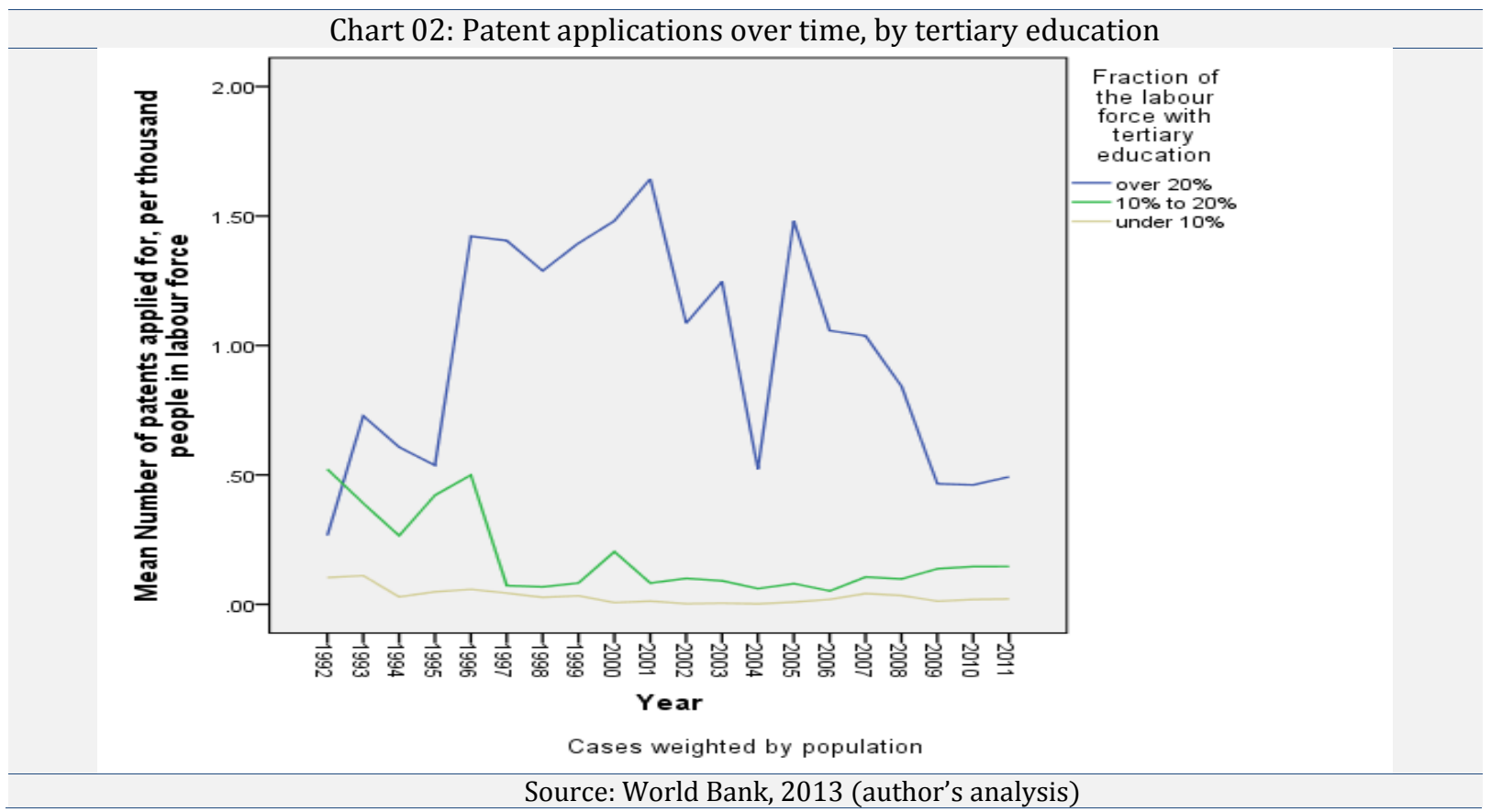

Chart 2 uses some of the same data as Chart 1; but Chart 2 uses patents, rather than productivity, to measure performance. There seems a clear pattern that countries with a more educated workforce tend to apply for more patents, illustrated by the fact that the line representing countries with over $20 \%$ of their workforce being graduates is higher. This is consistent with the hypothesis that tertiary education tends to make a workforce more effective. In countries where fewer than $10 \%$ of workers have tertiary education, very few patents are applied for (by residents): such countries seem in danger of being left behind in the competition to use new technologies.

Chart 3 is similar to Chart 2, but the height of each line in Chart 3 depends on registered trademarks (rather than patents) applied for by each country's residents. There is a clear pattern: in countries where over $20 \%$ of the workforce have tertiary education, more trademarks are applied for. This suggests that in highly educated countries, employees are better able to innovate by creating new products.

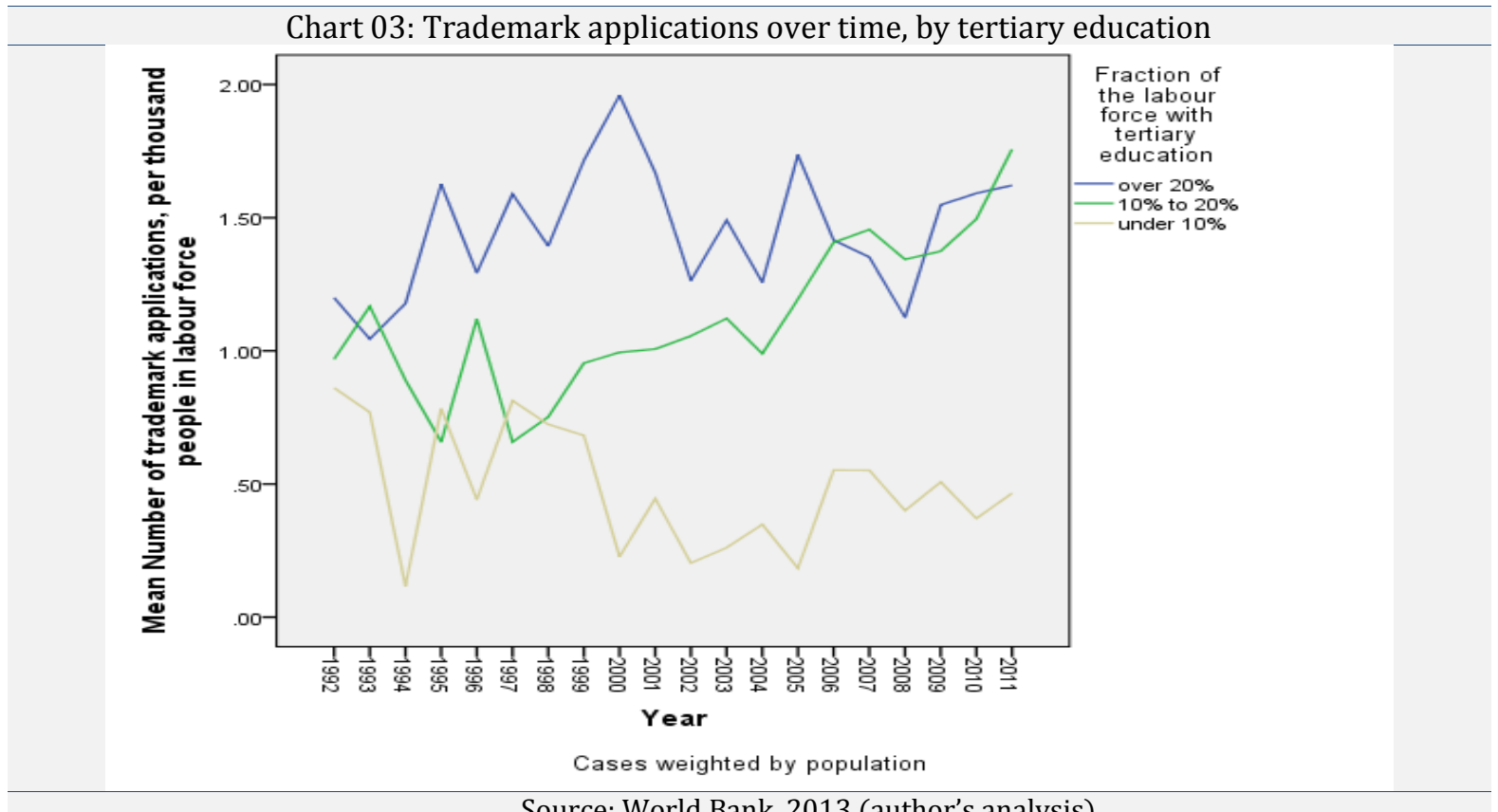

Source: World Bank, 2013 (author's analysis) 
Economists often seek to identify cause and effect. For WDI data, this is difficult to assess because there are many inter-relationships: for example, countries with high productivity may be more successful in exporting, and hence attract 'Foreign Direct Investment'. Other factors which could be affected by a productive workforce include low unemployment, and high wages. This suggests countries with high productivity tend to be rich; and rich countries are better able to afford to provide university education (whether state or privately-funded). Could the pattern in Chart 1 indicate that high productivity causes more tertiary education, rather than productivity being an effect of education? Many economists refer to 'Granger causality': if two events seem related, it is likely that the first event is the cause and the second the effect. To assess delayed effects, time-series regression is used (see appendix) regression analysis clearly shows that increasing education tends to precede growth in productivity by several years.

Table 1 reports the estimated effects of tertiary education on productivity in 17 countries, based on World Bank WDI data for 1990 to 2011 - explained in the appendix. The largest coefficient is lag 3 : implying that if the number of graduates increases by $1 \%$, this will be associated with a $7.51 \%$ increase in average productivity three years later (if no other changes occur). Productivity falls at around 4 to 6 years after an increase in tertiary education discussed below.

\begin{tabular}{cc}
\hline $\begin{array}{c}\text { Table 01: Apparent effects of education on productivity, from ARIMA regression. } \\
\text { Tertiary education, } \\
\text { by years' delay }\end{array}$ & $\begin{array}{c}\text { Estimated effect of education } \\
\text { on productivity }\end{array}$ \\
\hline$E_{1}$ & -1.20 \\
$E_{1}$ & -0.24 \\
$E_{2}$ & 4.98 \\
$E_{3}$ & 7.51 \\
$E_{4}$ & -6.00 \\
$E_{5}$ & -1.89 \\
$E_{6}$ & -6.47 \\
$E_{7}$ & 2.63 \\
$E_{8}$ & 4.31 \\
$E_{9}$ & -0.73 \\
$E_{10}$ & 0.44 \\
$E_{11}$ & 2.15 \\
\hline
\end{tabular}

The following evidence refers to the case study, Britain, beginning with FES data. Unlike WDI data, FES surveys do not report productivity; instead, bonuses are used as a proxy for productivity, assuming bonuses are performancerelated. In FES, a 'graduate' is defined as a person who left full-time education at age 19 or older.

Table 2 has several lessons. First, graduates generally have higher bonuses than non-graduates, implying graduates are far more productive. Secondly, non-graduates in Table 2 have a fairly steady increase, but graduates show a non-linear pattern of bonuses over time: for example, average bonuses fall from $£ 10.71$ at 3 years after leaving education, to $£ 7.74$ at 4 years after leaving education. Values which seem higher than we would expect are at 3,7 , and 8 years after leaving education; these lags are similar to positive values in Table 1 (bonuses cannot be negative). The non-linear pattern in productivity (in WDI data: Table 1) seems to be reflected in bonuses in FES data (in Table 2).

\begin{tabular}{ccc}
\hline \multicolumn{3}{c}{ Table 02: Bonus earnings (gross), by education level and time since left education } \\
\hline Years since leaving full-time education & Non-graduate & Graduate \\
\hline 0 & 0.30 & 0.22 \\
1 & 0.77 & 1.87 \\
2 & 0.97 & 7.52 \\
3 & 1.39 & 10.71 \\
4 & 1.63 & 7.74 \\
5 & 1.73 & 8.63 \\
6 & 2.56 & 10.09 \\
7 & 2.56 & 19.87 \\
8 & 3.32 & 19.50 \\
9 & 3.42 & 16.36 \\
10 & 3.61 & 15.58 \\
11 & 3.61 & 16.82 \\
$12+$ & 4.95 & 22.77 \\
& 84,508 cases & 30,700 cases \\
\hline
\end{tabular}

Why do graduate earnings apparently behave in this non-linear way? The author's analysis of FES data (not reported here) rejects the idea that this is due to maternity leave. Another possible explanation is that graduates 
have a non-linear career path - a hypothesis which can be explored using BHPS data, in Table 3. The list of occupations in Table 3 is from variable JBSEG (Institute for Social \& Economic Research, 2013): the author excluded 'own account' workers \& armed forces, and simplified the remaining 17 jobs into 7 rows; self-employed professionals are combined with employed professionals: "for professionals, independent practice and salaried employment are often indistinguishable" (Office for National Statistics, 2005: 11). Rows in Table 3 follow the order in BHPS data. The term 'foremen', in sources such as Office for National Statistics (2005), includes women. People outside the labour force (e.g. unemployed, ill, or on maternity leave) are excluded from Table 3.

Table 03: \% of graduates employed in different jobs, by time since leaving college/university

\begin{tabular}{|c|c|c|c|c|c|c|c|c|c|c|c|c|}
\hline $\begin{array}{l}\text { Number of years since leaving } \\
\text { college/university }\end{array}$ & 0 & 1 & 2 & 3 & 4 & 5 & 6 & 7 & 8 & 9 & 10 & 11 \\
\hline Manager (large organisation) & $2 \%$ & $4 \%$ & $6 \%$ & $7 \%$ & $10 \%$ & $11 \%$ & $13 \%$ & $14 \%$ & $17 \%$ & $17 \%$ & $20 \%$ & $22 \%$ \\
\hline Manager/employer (small organisation) & $4 \%$ & $5 \%$ & $4 \%$ & $6 \%$ & $5 \%$ & $8 \%$ & $7 \%$ & $7 \%$ & $5 \%$ & $5 \%$ & $10 \%$ & $4 \%$ \\
\hline Professional & $11 \%$ & $12 \%$ & $13 \%$ & $13 \%$ & $13 \%$ & $15 \%$ & $16 \%$ & $17 \%$ & $17 \%$ & $17 \%$ & $17 \%$ & $20 \%$ \\
\hline Intermediate (worker/foreman) & $33 \%$ & $41 \%$ & $44 \%$ & $45 \%$ & $48 \%$ & $46 \%$ & $44 \%$ & $42 \%$ & $42 \%$ & $42 \%$ & $38 \%$ & $40 \%$ \\
\hline Junior non-manual/personal service & $40 \%$ & $29 \%$ & $25 \%$ & $23 \%$ & $18 \%$ & $15 \%$ & $15 \%$ & $15 \%$ & $14 \%$ & $14 \%$ & $11 \%$ & $10 \%$ \\
\hline Manual foreman/skilled manual worker & $2 \%$ & $2 \%$ & $2 \%$ & $2 \%$ & $3 \%$ & $2 \%$ & $4 \%$ & $4 \%$ & $3 \%$ & $3 \%$ & $2 \%$ & $1 \%$ \\
\hline Semi-skilled/unskilled manual; farming & $7 \%$ & $5 \%$ & $5 \%$ & $4 \%$ & $2 \%$ & $3 \%$ & $2 \%$ & $1 \%$ & $2 \%$ & $2 \%$ & $2 \%$ & $2 \%$ \\
\hline Total (\%) & 100 & 100 & 100 & 100 & 100 & 100 & 100 & 100 & 100 & 100 & 100 & 100 \\
\hline sample size & 779 & 694 & 629 & 561 & 493 & 430 & 365 & 318 & 260 & 207 & 168 & 135 \\
\hline
\end{tabular}

Source: BHPS (author's analysis); rounded to nearest whole number.

Table 3 outlines careers of British graduates, for eleven years after leaving college/university (for the first time). The sample-size falls from left to right, partly because some people left college/university recently, and were interviewed in few BHPS surveys. Looking from left to right, graduates tend to proceed from lower-paid jobs (near the bottom of Table 3) to higher-paid jobs (near the top of Table 3). Only about $2 \%$ became managers in a large organisation in the first year (year zero) of graduating. We see a falling number of graduates in lower-paid jobs such as 'Junior non-manual/personal service worker', from $23 \%$ in year 3 to $18 \%$ in year 4 ; this suggests many graduates do not make the transition from low-paid to high-paid jobs without several years' work experience.

Could career paths in Table 3 explain non-linear patterns in Tables 1 and 2? Table 2 shows British graduates tend to experience falling bonuses from 4 to 6 years after graduating, perhaps because they need to learn new skills (hence become temporarily less productive) when promoted. In Table 2, promotion to manager in a large organisation occurs most often from year 3 (7\% to 10\%), and from year 7 (14\% to 17\%), after leaving college/university. These steps correspond approximately to falling bonuses received by graduates: but in table 2, bonuses fall just after years 3 and 8 years (rather than after 3 and 7 years). Comparisons between Table 2 and 3 should be treated with caution, due to different methods. In Britain, most graduates leave higher education in summer; BHPS interviews usually occur in September or October. Hence, column 0 in Table 3 represents people interviewed a few months after leaving university. In contrast, FES data in Table 2 use 'terminal education age' and employee's age (at the time of interview), both rounded down to whole numbers.

Comparison becomes more complicated if we compare British data with international data in Table 1: graduates in different countries may have different career paths. More research is needed, to see if British behavior applies in other countries. Despite these reservations, the non-linear patterns in tables 1, 2, and 3 seem similar - suggesting delays between a person graduating and their productivity increasing follows a non-linear pattern. A possible interpretation of falling productivity after year 3 is promotion to senior management, which occurs mainly to graduates who began their career in junior non-manual or personal service jobs; the productivity fall after year 8 or 9 may be due to graduates who began their career in manual work, and took years to obtain a non-manual job before proceeding to management or professional jobs. This could be called the 'valence hypothesis': graduate promotion in steps is analogous to electrons rising to higher shells in an atom. In this valence analogy, each row in Table 3 is like an electron shell in an atom (and a worker's productivity is like an electron's energy level).

\subsection{Conclusion and policy implications}

This paper uses three data sources. The first source is macroeconomic data from World Bank, giving an overview of global trends. This paper also uses Britain as a case study, with two microeconomic data sources: FES surveys 
report bonuses of individual workers, revealing links between a person's education and their productivity; and BHPS data show career paths of graduates.

New evidence in this paper clarifies causality: it shows tertiary education is a cause, and increased productivity (leading to economic growth) an effect. This paper shows a sequence of events after someone leaves higher education: many graduates start in low-paid employment (Table 3), but graduates generally obtain higher bonuses than non-graduates (Table 2) - a person tends to be a more effective employee, if he or she is a graduate. There appear to be career setbacks (in Table 2): bonuses fall at about 3 and 8 years after graduation. But Table 3 shows these setbacks are not failures but successes, associated with graduates achieving promotion.

Graduates tend to receive much higher bonuses than non-graduates (Table 2). Holland et al. (2013: 38-9) claim "under market principles, there should be a strong correlation between wage differentials and productivity differentials. Under the extreme assumption of perfectly competitive markets, a firm will hire an additional hour of labour up to the point where that person's marginal product equals his/her marginal cost. Under this assumption, the wage premium of graduates should reflect their productivity premium relative to low-skilled workers." Hence, bonuses in Table 2 indicate that graduates tend to be more productive than non-graduates. This is supported by Charts 1 to 3 .

As a provider of medical advice, a medical graduate is safer than someone who never went to university; even better than a recent graduate, is a graduate who has worked in a hospital for years. If deciding whether a factory is profitable, it makes sense to ask a graduate - but preferably a graduate with work experience. Similarly, a bridge would probably be safer if the designer studied engineering at university, but even safer if he or she also has work experience.

Scholarly tradition, and scientific method, suggests we should not rely on a hypothesis unless it is supported by several researchers. This paper confirms and builds on previous research discussed in the literature review, such as Holland et al. (2013: 60). Holland et al. (2013: 59) wrote "The role of Higher Education (HE) in improving economic growth and competitiveness is widely acknowledged and supported by the literature, although many of the existing studies are based on outdated datasets and proxy variables for productivity and workforce skills that are subject to a significant degree of measurement error. Nonetheless, policy makers face a dilemma over the amount of public resources that should be devoted to education, especially at present as they try to regain control over public finances in the wake of the financial crisis." Colleges and universities are vital for future prosperity: tertiary education improves productivity. Freeman \& Van Reenen (2009: 7) claim private firms invest too little in education and research, justifying government spending. More state funding for education is required.

\section{References}

Bapna R., Langer N., Mehra A., Gopal R., Gupta A., 2013. Human capital investments and employee performance: an analysis of IT services industry. Management Science, 59(3): 641-658. http://dx.doi.org/10.1287/mnsc.1120.1586

Cockburn I.M., Slaughter M.J., 2010. The global location of biopharmaceutical knowledge activity: new findings, new questions. Innovation Policy and the Economy, 10(1): 129-157. http://dx.doi.org/10.1086/605855

Department of Employment and Learning, 2009. The influence of graduate qualifications on average wages and productivity across the UK. UK government (Northern Ireland). Retrieved from: http://www.delni.gov.uk/report_graduate_productivity_final.pdf.pdf (Accessed date: 16 December 2013).

European Commission, 2010. An agenda for new skills and jobs: a European contribution towards full employment. Retrieved from: http://eur-lex.europa.eu/LexUriServ/LexUriServ.do?uri=COM:2010:0682:FIN:en:PDF (Accessed date: 11 April 2014).

Fox J.T., Smeets V., 2011. Does input quality drive measured differences in firm productivity? International Economic Review, 52(4): 961-989. http://dx.doi.org/10.1111/j.1468-2354.2011.00656.x

Freeman R., Van Reenen J., 2009. What if Congress doubled R\&D spending on the physical sciences? Innovation Policy and the Economy, 9(1): 1-38. http://dx.doi.org/10.1086/592419

Gordon E.G., 2009. Winning the global talent showdown: how businesses \& communities can partner to rebuild the jobs pipeline. San Francisco: Berrett-Koehler.

Hanushek E.A., Wößmann L., 2007. Education quality and economic growth. Washington DC: The World Bank. Retrieved from: http://siteresources.worldbank.org/EDUCATION/Resources/2782001099079877269/547664-1099079934475/Edu_Quality_Economic_Growth.pdf (Accessed date: 15 December 2013).

Holland D., Liadze I., Cinzia Rienzo C., Wilkinson D., 2013. The relationship between graduates and economic growth across countries. Department for Business Innovation \& Skills, BIS research paper 110. Retrieved from: https://www.gov.uk/government/uploads/system/uploads/attachment_data/file/229492/bis-13-858- 
relationship-between-graduates-and-economic-growth-across-countries.pdf (Accessed date: 16 December 2013).

Institute for Social \& Economic Research, 2013. AJBSEG: Socio economic group: present job. BHPS Documentation and Questionnaires, Institute for Social \& Economic Research. Retrieved from: https://www.iser.essex.ac.uk/bhps/documentation/volb/wave1/aindresp18.html\#AJBSEG (Accessed date: 29 December 2013).

Lefrere P., 2007. Competing Higher Education futures in a globalising world. European Journal of Education, 42(2): 201-212. http://dx.doi.org/10.1111/j.1465-3435.2007.00301.x

Office for National Statistics, 2005. The National Statistics socio-economic classification user manual. Basingstoke: Office for National Statistics/Palgrave Macmillan. Retrieved from: www.ons.gov.uk/ons/guidemethod/classifications/archived-standard-classifications/soc-and-sec-archive/the-national-statistics-socioeconomic-classification--user-manual.pdf (Accessed date: 29 December 2013).

Organisation for Economic Co-operation and Development, 2012. What are the key growth factors? The theory, in OECD (Ed.), Promoting growth in all regions, Paris: OECD publishing. doi: 10.1787/9789264174634-6-en Retrieved from: http://www.oecd-ilibrary.org/urban-rural-and-regional-development/promoting-growth-inall-regions/what-are-the-key-growth-factors-the-theory_9789264174634-6-en (Accessed date: 11 April 2014). http://dx.doi.org/10.1787/9789264174634-6-en

Pissarides C.A., 2011. Regular education as a tool of counter-cyclical employment policy. Nordic Economic Policy Review, 1, 209-232.

Quiggin J., 1999. Human capital theory and education policy in Australia. Australian Economic Review, 32(2): 130144. http://dx.doi.org/10.1111/1467-8462.00100

Rohling T.A., 1986. Screening and Human Capital Theory: an empirical test. Relations Industrielles / Industrial Relations, 41(4): 817-826.

Simister J., 2011. Elitism and meritocracy in UK universities: the UK needs investment in its labour force. Higher Education Quarterly, 65(2): 113-144. http://dx.doi.org/10.1111/j.1468-2273.2010.00476.x

Taylor M.F., Brice J., Buck N., Prentice-Lane E., 2010. British Household Panel Survey User Manual Volume A: Introduction, Technical Report and Appendices. Colchester: University of Essex. Retrieved from: https://www.iser.essex.ac.uk/bhps/documentation/vola/vola.html (Accessed date: 29 December 2013).

UK Data Service, 2013. Family Expenditure Survey. Retrieved from: http://discover.ukdataservice.ac.uk/series/?sn=200016 (Accessed date: 31 December 2013).

United Nations Educational, Scientific and Cultural Organisation, 2012. International Standard Classification of Education: ISCED 2011. Montreal: UNESCO Institute for Statistics. Retrieved from: http://www.uis.unesco.org/Education/Pages/international-standard-classification-of-education.aspx (Accessed date: 30 December 2013).

University of Essex, 2010. British Household Panel Survey: Waves 1-18, 1991-2009, SN: 5151. 7th edition. Colchester: Institute for Social and Economic Research / UK Data Archive [distributor].

Wang H.C., He J., Mahoney J.T., 2009. Firm-Specific knowledge resources and competitive advantage: The roles of economic- and relationship-based employee governance mechanisms. Strategic Management Journal, 30(12): 1265-1285. http://dx.doi.org/10.1002/smj.787

World Bank, 2013. Labor force with tertiary education (\% of total). World Development Indicators database. Retrieved from: http://data.worldbank.org/indicator/SL.TLF.TERT.ZS?page=1 (Accessed date: 17 October 2013).

\section{Appendix}

This appendix provides details on the regression analysis for this paper. To estimate how graduate skills affect GDP growth, Holland et al. (2013: 40) assumed workers are on average paid their marginal product, and compared graduates to people without educational qualifications.

Fox \& Smeets (2011) discuss problems with regression analysis of education and productivity, e.g. there may not be a linear relationship between the fraction of a firm's workforce who have a degree, and the firm's productivity. According to Holland et al. (2013: 29), most cross-country regression studies assessing the relationship between growth and education use GDP per capita to measure productivity; but Holland et al. prefer to measure labour productivity using GDP per employment hour. This paper uses 'value added', divided by number of people in the labour force (assuming people in every country work a similar number of hours per year).

The Cobb-Douglas production function is used by many economists, to estimate how output is affected by labour and capital inputs; it takes a form similar to equation (01).

$\mathrm{Y}=\mathrm{A}(\mathrm{h}, \mathrm{Z}) \mathrm{k}^{\alpha} \mathrm{h}^{(1-\alpha)}$

Eq (01) 
In equation (01), $h$ is a measure of human capital (including education); $A(h, Z)$ is a function of human capital $h$ and control variables such as trade openness; $\mathrm{k}$ measures physical capital per employee; and $\alpha$ is an unknown parameter.

One approach to investigating links between education and productivity is to use the Mincer equation, with productivity as dependent variable and years of education as a possible cause - controlling for variables such as work experience (Holland et al., 2013: 25). Holland et al. (2013: 14) report that most empirical studies of the longrun relationship between education and growth are based on equation (02). Equation (02) is derived by taking the $\log$ of both sides of equation (01). In equation (02), Ln represents the natural $\log$; and $\varepsilon$ represents other (unmeasured) influences on productivity.

$\operatorname{Ln}(\mathrm{y})=\operatorname{Ln}(A(\mathrm{~h}, \mathrm{Z}))+\alpha \operatorname{Ln}(\mathrm{k})+(1-\alpha) \operatorname{Ln}(\mathrm{h})+\varepsilon$

In time-series data, regression using a specification like equation (02) may produce spurious results due to autocorrelation (Holland et al., 2013: 56); hence, equation (03) is widely used to assess the effects of human capital on growth (Holland et al., 2013: 15):

$\Delta \operatorname{Ln}(\mathrm{y})=\beta_{1} \Delta \operatorname{Ln}(A(\mathrm{~h}, \mathrm{Z}))+\beta_{2} \Delta \operatorname{Ln}(\mathrm{k})+\beta_{3} \Delta \operatorname{Ln}(\mathrm{h})+\eta$

Equation (03) uses similar notation to equation (02), with $\Delta$ representing the first-difference; and $\eta$ controlling for other influences. Holland et al. (2013: 15) use lagged values, but include factors beyond the scope of this paper such as trade openness.

This paper uses a distributed-lag regression to allow estimation of time-lags between increased education, and increased productivity; productivity and education data are explained in the 'materials and methods' section. The author's analysis of World Bank data indicates autocorrelation: first-order correlation coefficients are 0.945 for productivity, and 0.691 for education (both statistically significant at the $1 \%$ level). Hence ARIMA regression is used, with parameters $(1,1,0)$ to produce the regression specification in equation $(04)$.

$\Delta \mathrm{P}=\alpha+\mathrm{AR} 1+\beta_{0}(\Delta \mathrm{E})+\beta_{1}(\Delta \mathrm{E})_{1}+\beta_{2}(\Delta \mathrm{E})_{2}+\beta_{3}(\Delta \mathrm{E})_{3}+\ldots+\beta_{11}(\Delta \mathrm{E})_{11}+\eta \quad \mathrm{Eq}(04)$

In equation (04), P represents productivity per person-hour; E is the percentage of the labour force with tertiary education (a continuous variable, rather than the simplified variable in Chart 1 with just three values). AR1 is an autocorrelation term, and $\eta$ an error term. Subscripts represent lagged values: for example, $(\Delta E)_{3}$ is the increase in the percentage of graduates 3 years before the productivity rise $(\Delta \mathrm{P})$ was measured. Data are not weighted; the ARIMA algorithm (in SPSS software) includes a Kalman filter. Estimated coefficients $\alpha$, AR1, and $\beta_{0}$ to $\beta_{11}$ are reported as 'Model 1' in Table 4. Table 4 adds a second regression specification, 'Model 2': identical to equation 1, but with a dummy variable for each country except UK (e.g. variable 'Austria' equals 1 for Austrian data, or zero for other countries). UK is the reference country; for example, the negative coefficient for Bulgaria indicates that a Bulgarian employee generally has lower productivity than a UK employee, even controlling for education level.

\begin{tabular}{lcc}
\hline & Table 04: ARIMA regression results \\
\hline Variable & Model 1 & Model 2 \\
\hline Constant & -0.002 & -0.001 \\
AR1 & $-0.03^{*}$ & $-0.15^{* *}$ \\
$\beta_{0}$ & -1.20 & -1.82 \\
$\beta_{1}$ & -0.24 & -1.14 \\
$\beta_{2}$ & $4.98^{* *}$ & $5.48^{* *}$ \\
$\beta_{3}$ & $7.51^{* *}$ & $7.72^{* *}$ \\
$\beta_{4}$ & $-6.00^{* *}$ & $-7.85^{* *}$ \\
$\beta_{5}$ & $-1.89^{*}$ & $-2.10^{* *}$ \\
$\beta_{6}$ & $-6.47^{* *}$ & $-7.94^{* *}$ \\
$\beta_{7}$ & $2.63^{* *}$ & $2.33^{* *}$ \\
$\beta_{8}$ & $4.31^{* *}$ & $3.25^{* *}$ \\
$\beta_{9}$ & -0.73 & $-1.37^{* *}$ \\
$\beta_{10}$ & 0.44 & 0.06 \\
$\beta_{11}$ & $2.15^{* *}$ & $1.86^{* *}$ \\
\hline Austria & & 247.41 \\
Bulgaria & & $-1340.4^{* *}$
\end{tabular}




\begin{tabular}{lc} 
Costa Rica & $-642.57^{* *}$ \\
Denmark & $823.50^{* *}$ \\
Finland & $838.76^{* *}$ \\
Germany & $540.38^{* *}$ \\
Iceland & $742.16^{* *}$ \\
Italy & $-627.72^{* *}$ \\
Latvia & $-556.97^{* *}$ \\
Luxembourg & $1392.96^{* *}$ \\
Netherlands & $-1165.7^{* *}$ \\
Poland & $-353.41^{* *}$ \\
Romania & $-412.03^{* *}$ \\
Slovenia & 57.91 \\
Sweden & $-236.69^{* *}$ \\
Trinidad/Tobago & 100.85 \\
\hline \multicolumn{2}{r}{ Source: World Bank WDI data (see text), analyzed by the author. } \\
& UK is the reference country for the 'Model 2' regression. \\
\hline
\end{tabular}

Both regressions in Table 4 have 4,415 residuals. Country variables in regression 2 are not relevant to this paper, but reduce the risk of spurious results: effects of education, shown as coefficients $\beta_{0}$ to $\beta_{11}$, are robust to changing the regression equation from Model 1 to Model 2 - the largest $\beta$ coefficients remain at $\beta_{2}, \beta_{3}, \beta_{7}$ and $\beta_{8}$. These lags $(2,3,7$ and 8$)$ are similar to the pattern for graduates in Table 2 . 